\title{
WARAK NGENDOG DALAM TRADISI DUGDERAN SEBAGAI REPRESENTASI IDENTITAS MUSLIM URBAN DI KOTA SEMARANG
}

\author{
Cahyono \\ Universitas Kristen Satya Wacana, Salatiga - Indonesia \\ e-mail: anantatoer.cahyo@gmail.com
}

\begin{abstract}
This research aims to explore how Warak Ngendog in the Dugderan tradition represents the identity of urban Muslim communities in the city of Semarang. This research also aims to expose the strength of the city's Muslim culture that has been maintained to this day. This study uses an identity theory approach by Peter J. Burke and Homi K. Bhabha about Hybrid culture, and several other extraordinary theories as supporting theories. This research uses a qualitative descriptive approach with the support of substantive information from archives and interviews with related figures. The results of this study emphasize that the dynamics of the religiosity of urban Muslim communities in Semarang City shape urban Muslim identity. Acculturation of the traditional culture of Javanese, Arab and Chinese Muslims symbolizes the new religious and cultural rites as an inseparable part of the urban Muslim identity of Semarang City because there are social interactions in their involvement in religious rituals, traditions and culture.
\end{abstract}

\begin{abstract}
Abstrak: Penelitian ini bertujuan untuk mengeksplorasi bagaimana Warak Ngendog dalam tradisi Dugderan mewakili identitas masyarakat Muslim urban (perkotaan) di Kota Semarang. Penelitian ini juga menargetkan untuk mengekspos kekuatan budaya Muslim urban yang dipertahankan hingga saat ini. Penelitian ini menggunakan pendekatan teori identitas Peter J. Burke dan Homi K. Bhabha tentang persilangan budaya, dan beberapa teori luar biasa lainnya sebagai teori pendukung. Penelitian ini menggunakan pendekatan deskriptif kualitatif dengan dukungan informasi substantif dari arsip dan wawancara dengan tokoh-tokoh terkait. Hasil penelitian ini menekankan bahwa dinamika religiusitas komunitas Muslim urban di Kota Semarang membentuk identitas Muslim urban. Akulturasi budaya tradisional Muslim Jawa, Arab, dan Cina melambangkan ritus agama dan budaya baru sebagai, bagian tak terpisahkan, identitas Muslim urban Kota Semarang karena ada interaksi sosial dalam kegiatan keterlibatan mereka dalam ritual keagamaan, tradisi, dan budaya.
\end{abstract}

Keywords: warakngendog; dugderan tradition; identity of urban Muslim; Semarang City

\section{A. Pendahuluan}

Salah satu fenomena yang menguat pasca reformasi adalah maraknya publikasi berbagai diskursus mengenai religiusitas Muslim di Indonesia. Dari 
sana, tergambar bahwa wacana identitas Islam di Indonesia menjadi isu menarik, utamanya di kalangan sarjana sosiologi agama. Tampak pula di sana gambaran tentang proses terbentuknya sebuah identitas keagamaan yang terus berkembang seiring konteks zaman.

Kajian tentang identitas Islam di Indonesia, dalam salah satu tipologinya, mengambil sudut pandang soal hubungan antara universalitas Islam dengan lokalitas. Ini misalnya tercermin dalam bahasan mengenai Islam Bajo. Identitas keagamaan orang Bajo merupakan perpaduan antara keyakinan Islam dengan keyakinan asli mereka, yaitu keyakinan kepada para penguasa laut, atau yang mereka sebut sebagai Mbao Ma Dilao. ${ }^{1}$ Identitas keagamaan orang Bajo dibentuk dalam pengaruh dan dinamika lingkungan alam, sosial, dan historis masyarakat Bajo. ${ }^{2}$ Orang Bajo memiliki tradisi upacara persembahan terhadap penguasa laut (sebagai bentuk syukur) di mana laut merupakan tempat mereka bermukim dan mencari kehidupan. ${ }^{3}$

Pasca reformasi 1998, munculnya simbol-simbol ritual keagamaan sebagai salah satu identitas masyarakat urban kian menguat. Simbol-simbol sebagai representasi sesuatu yang abstrak dan menjadi narasi besar, menguat di kalangan masyarakat. Situasi ini di antaranya merepresentasi pada masyarakat Muslim urban di Kota Semarang yang menunjukkan adanya perkembangan suatu model interaksi modernis-tradisionalis dalam bingkai tradisi lokal. Di satu sisi ada fakta betapa meluasnya pembangunan fisik seperti pasar modern, gedung-gedung tinggi, pusat administrasi pemerintahan, perumahan elit dan pembangunan fisik lainnya. Di sisi lain relasi sosial yang berkembang dalam masyarakat urban Semarang masih bernuansa santri, setidaknya corak Islam tradisional ini masih kental dan terjaga. Di sinilah penulis hendak mengambilnya sebagai objek kajian.

\footnotetext{
${ }^{1}$ Merupakan inkarnasi dari nenek moyang mereka yang menguasai laut. Keyakinan yang tumbuh dari pemahaman dan pengaruh atas lingkungan sosial orang Bajo. Keyakinan asli inilah yang menjadi karakteristik keberislaman mereka sebagai orang Bajo yang bermukim di laut.

${ }^{2}$ Francois Robert Zacot, Orang Bajo Suku Pengembara Laut: Pengalaman Seorang Antropolog (Jakarta: KPG, 2002).

${ }^{3}$ Benny Baskara, Islam Bajo Agama Orang Laut (Banten: Javanica, 2016), 261-263; Nur Syam, Islam Pesisir (Yogyakarta: LKiS, 2005). Nur Syam ingin menjelaskan bahwa konstruksi sosial dalam masyarakat Pesisir, terjadi hubungan antara Islam dan budaya lokal yang bercorak akulturatifsinkretik sebagai hasil konstruksi bersama antara agen dengan masyarakat dalam sebuah proses dialektika yang terjadi secara terus menerus.
} 
Place atau tata ruang kota dan juga karakter masyarakat urban sangat bertaut dengan pola keberagamaannya. Penelitian ini hendak menjadikan Warak Ngendog dalam tradisi Dugderan sebagai fokus penelitian. Tepatnya, penelitian ini akan menelisik Warak Ngendog dalam tradisi Dugderan sebagai representasi identitas Muslim urban di Kota Semarang dengan dibatasi pada era pasca reformasi. Semarang yang dimaksud dalam penelitian ini adalah Kota Semarang, mengingat Semarang sendiri terbagi ke dalam dua admnistrasi; Kota dan Kabupaten.

Seperti diketahui, masyarakat urban mula-mula dibagi dalam kotak-kotak rapat oleh struktur sosial ganda (plural). Batas-batas interaksi antara kelompokkelompok etnis telah memudar akibat bangunan-bangunan perkotaan dan penduduk yang kian padat. Clifford Geertz, dalam studinya tentang sebuah kota kecil di Jawa, menyayangkan tidak adanya integrasi antara berbagai kelompok etnis dan budaya di dalam kota. Geertz menggunakan istilah "hollow town" (kota kosong) untuk menggambarkan situasi di mana suatu masyarakat kota bukan merupakan struktur sosial yang terintegrasi, namun lebih bersifat kombinasi dari masyarakat-masyarakat kecil. ${ }^{4}$

Menilik sejarah lahirnya Kota Semarang, kita dapat diarahkan pada beberapa karya seperti yang ditulis Liem, dan Amen Budiman, bahwa lahirnya Kota Semarang bermula dari penamaan suatu daerah (kota, dusun, kampung, sungai, gunung) berdasarkan pada ciri khas daerah itu, keadaan alam atau pemandangan mencolok di sekitarnya. Menurut Serat Kandaning Ringgit Purwa Naskah KBG NR.7, lahirnya Kota Semarang diawali pada tahun 1938 Saka (1476 M), dengan datangnya utusan Kerajaan Demak (Ki Pandan Arang) yang mengemban tugas pengislaman di wilayah barat Kerajaan Demak, di Semenanjung Pulau Tirang (sekarang daerah Mugas dan Bergota, Semarang). Sesampainya di daerah ini, ia mendirikan pesantren. Di daerah yang subur ini tumbuh pohon asam (Jawa: asem) yang masih jarang (Jawa: arang). Muridnya dari waktu ke waktu semakin banyak, dan tempat itu kemudian semakin dikenal banyak orang: daerah asem-arang, diucapkan Semarang. 5 204.

${ }^{4}$ Clifford Geertz, The Social History of an Indonesia Town (Ithaca, N.Y: M.I.T. Press, 1967), 153-

${ }^{5}$ Freek Colombijn dan Martine Barwegen, Kota Lama, Kota Baru: Sejarah Kota-Kota di Indonesia Sebelum dan Setelah Kemerdekaan, terj. Purnawan Basundoro dan Johny Alfian Kusyairi (Yogyakarta: Ombak, 2005), 150-151.

JURNAL THEOLOGIA — Volume 29, Nomor 2, Desember 2018 
Kedatangan pedagang timur asing ke Semarang telah mewarnai corak kota ini, selain pribumi dan orang Eropa. Antara tahun 1920-1930 Semarang banyak didatangi orang-orang Eropa. Diduga mereka pergi ke Semarang dan kota lain di Hindia Belanda untuk mencari pekerjaan. ${ }^{6}$ Akibatnya, Semarang mempunyai penduduk dari beragam etnis: Jawa, Cina, Arab, Melayu, India, dan orang Eropa. Barangkali identitas dan karakteristik masyarakat urban di kota Semarang merupakan salah satu ekspresi keberagamaan multikultural di Indonesia. ${ }^{7}$

Di samping masyarakatnya yang mayoritas pedagang, Kota Semarang secara etnografis juga merupakan salah satu kota dengan nuansa kampung santri dari sekian banyak kota di Indonesia. Meminjam apa yang dikatakan Djawahir Muhammad, budayawan terkemuka di Semarang, bahwa Semarang sebagai kota yang disiapkan Belanda sebagai kota perdagangan, masyarakatnya selain kosmopolit juga punya spirit sebagai pedagang. Pasalnya pedagang memiliki prinsip bahwa lebih baik jadi juragan kecil daripada jadi kacung besar. Hal ini yang kemudian berpengaruh terhadap pola keberislamannya. ${ }^{8}$ Salah satu syarat bagi masyarakat yang ingin berkembang adalah kesediaan mereka untuk menerima spirit keberagaman (pluralisme), kesetaraan (multikulturalisme) dan keterpaduan (akulturasi, hybridasi), yang hanya dapat dimungkinkan apabila anggota komunitas itu bersedia melakukan proses menerima kelebihan dan kekurangan masing-masing.

Konteks perkembangan tradisi dan budaya Semarangan, pertemuan sumber-sumber tradisi, budaya dan kearifan lokal di atas merupakan suatu kondisi yang hampir terabaikan. Dari sini ada kekhawatiran kehilangan identitas dan personal integritasnya. Kekhawatiran ini dapat diamati dari peningkatan apresiasi masyarakat terhadap elemen-elemen visual budaya hybrid masyarakat di kota ini. Misalnya pemilihan selera makanan, itu sama sekali tidak menunjukkan keberpihakan terhdap unsur kearifan lokal. Tidak ada yang salah dengan akulturasi, pluralisme, multikulturalisme dan hybrid culture. Namun bagi Bhabha, antara teori dan praktek tidak dapat dipilih salah satu saja untuk dikritik. Teori dan praktek berada bersebelahan. Teori adalah wahana ideologi dan dalam

\footnotetext{
${ }^{6}$ Liem Thian Joe, Riwajat Semarang: Dari Djamannja Sam Poo Sampe Terhapoesnja Kongkoan (Semarang: Ho Kiem Yoe, 1933), 20.

${ }^{7}$ Colombijn dan Barwegen, Kota Lama, Kota Baru....

${ }^{8}$ Interview dengan Djawahir Muhammad, Budayawan Semarang, pada tanggal 27 Maret 2017 dilakukan di kediamannya, di Semarang.
} 
mewujudkannya teori menciptakan situasi politis. Dengan menyandingkan teori dan praktek, Bhabha berusaha menemukan pertalian dan ketegangan antara keduanya yang melahirkan hibriditas. Bhabha melukiskan bagaimana budayabudaya itu bergerak keluar masuk ruang ketiga dengan indahnya. ${ }^{9}$

Tradisi lokal Semarang mengintegrasikan keragaman budaya dan toleransi pada sesama etnis. Tradisi Dugderan diwarnai dengan simbol-simbol ritus keagamaan dan kebudayaan masyarakat Kota Semarang. Warak Ngendog sebagai simbol dalam tradisi Dugderan merepresentasikan keterpaduan sosial yang ditopang oleh keberadaan tiga entitas penduduknya; Jawa, Cina, Arab. Tradisi Dugderan sebagai warisan pesisir Jawa (Islam) kini menjadi momen bersama bagi masyarakat Semarang. Proses pemaknaan masyarakat atas simbol Warak Ngendog, menjadikannya ikon dalam tradisi Dugderan sebagai tradisi lokal masyarakat Kota Semarang. Meminjam teori interaksi simboliknya Mead, bahwa terbentuknya perilaku manusia dipengaruhi oleh pemahamannya pada simbolsimbol di lingkungan di mana ia tinggal dan berkat interaksinya dengan manusia yang lain.10

Menurut penelitian sejarah Amen Budiman bahwa Kota Semarang mengawali sejarahnya sebagai sebuah dusun nelayan yang kecil, didirikan oleh Kyai Ageng Pandan Arang, seorang maulana dari negeri Arab yang nama aslinya Maulana Ibnu Abdullah. ${ }^{11}$ Hasil dari pengamatan awal di lapangan serta diskusi dengan beberapa tokoh di Semarang, bahwa masyarakat Muslim urban di Semarang merasa bukanlah Muslim yang harus mengembangkan agamanya secara ketat. Mereka adalah orang Muslim hanya saja tidak seperti yang berkembang di Kendal, Demak dan daerah pesisir lainnya dengan membangun pesantren. Konteks perubahan sosio kultural inilah yang hendak diulas dalam karya akademik ini.

Beberapa peneiltian lain yang berbicara tentang Semarang banyak berbicara pada sisi estetika seni dan etnisitasnya. ${ }^{12}$ Misalnya karya Supramono dalam

\footnotetext{
${ }^{9}$ Homy K. Bhabha, The Location of Culture (London and New York: Routletge, 1994), 36.

${ }^{10}$ George H. Mead dan Charles W. Morris, "Mind, Self, and Society from the Standpoint of a Social Behaviorist," The Philosophical Review 44, no. 6 (1935): 587-89, https://doi.org/ $10.2307 / 2179928$.

${ }^{11}$ Amen Budiman, Semarang Juwita: Semarang Tempo Doeloe, Semarang Masa Kini dalam Rekaman Kamera (Semarang: Tanjung Sari, 1979), 2.

${ }^{12}$ M. M. Sudarwani, "Simbolisasi Rumah Tinggal Etnis Cina: Studi Kasus Kawasan Pecinan Semarang," Jurnal Imiah Momentum 8, no. 2 (2012): 19-27, https://publikasiilmiah.unwahas.acid/
} 
tesisnya Makna Warak Ngendog dalam Tradisi Ritual Dugderan di Kota Semarang, mengulas lebih pada bagaimana makna Warak Ngendog ini sebagai karya seni yang memiliki nilai estetik. Sebagai karya seni, kata Supramono, Warak Ngendog menjadi magnet kesenian yang menghidupkan dalam tradisi ritual Dugderan. M. Sudarwani dalam "Simbolisasi Rumah Tinggal Etnis Cina: Studi Kasus Kawasan Pecinan Semarang", menawarkan sebuah hasil penelitian antropologinya mengenai makna atas arsitektur rumah pemukiman etnis Cina. Di mana arsitektur Cina dan Melayu mengalami percampuran, dan ini yang menjadi ciri khas kawasan Pecinan di Semarang dengan Pecinan lainnya. ${ }^{13}$ Tulisan tentang etnisitas yang agak kritis diperkenalkan oleh Tubagus P. Svarajati. Pecinan Semarang, ujarnya, merupakan kawasan yang diwariskan dari masa silam. Pecinan merupakan produk dari politik pemisahan yang dilakukan kalangan imperialis untuk melokalisasi penduduk berdasar kalkulasi rasialisme. ${ }^{14}$

Penelitian sebelumnya seperti yang dipaparkan di awal masih ada ruang yang belum terisi. Penelitian ini berupaya menggambarkan Warak Ngendog dalam tradisi Dugderan sebagai representasi identitas Muslim urban di Semarang dengan perspektif sosio-kultural. Bahwa transformasi ritus-ritus keagamaan masyarakat urban kental dengan nuansa zaman yang terus berkembang.

Penelitian ini menggunakan metode deskriptif kualitatif dengan dukungan informasi substantif dari arsip dan interview dengan tokoh-tokoh terkait. Dengan menggunakan metode ini, penulis menggali data dengan melakukan pengamatan di lapangan dan penelusuran bahan-bahan pustaka berupa literatur yang berkaitan dengan substansi penelitian. Pengumpulan data juga dilakukan melalui wawancara. Wawancara dilakukan kepada beberapa sumber yakni sejarawan, budayawan, dan unsur masyarakat. Sedangkan observasi di-

index.php/MOMENTUM/article/view/429. Sudarwani dalam penelitiannya dengan pendekatan antropologi, bahwa simbolisasi pada suatu komunitas ataupun etnis itu memiliki makna khusus. Dan etnis Cina di Semarang memiliki itu, terbukti, kata Sudarwani, dari sisi rumah tempat tinggal mereka. Pecinan sebagai pusaka (warisan) Indonesia yang terlibat dalam proses pembentukan identitas Semarang memiliki keistimewaan dan keunikan tersendiri. Hal demikian yang membedakan antara kawasan Pecinan Semarang dengan Pecinan lainnya. Simbolisasi rumah tinggal etnis Cina di kawasan tersebut merupakan hasil perpaduan antara arsitektur Cina bercampur dengan arsitektur Melayu.

${ }^{13}$ Sudarwani. 240-241.

14Tubagus P. Svarajati, Pecinan Semarang dan Dar-Der-Dor Kota (Semarang: Bukusaya, 2016), 
lakukan dangan cara terlibat langsung pada upacara tradisi masyarakat Semarang, Dugderan.

\section{B. Konstruksi Kultural sebagai Identitas Urban}

Merumuskan sebuah identitas perkotaan (urban) tak lepas dari karakteristik dan citra kota itu sendiri. Dalam hal ini, penulis hendak menguraikan identitas urban sebagai pintu masuk teori yang dapat membantu menjembatani kajian ini. Penulis memulai merumuskan kerangka teori identitas urban dengan menggunakan teori Kevin Lynch. Lynch, sebagai peneliti kota, karya-karyanya banyak dijadikan sebagai referensi primer dalam penelitian perencanaan atau identitas kota. Selain itu, teori identitas Sheldon Stryker, Peter J. Burke, 15 dan Chris Barker cukup mendukung dalam rumusan kerangka teori identitas urban ini. Di samping itu, sebagai upaya menelisik lahirnya proses persilangan budaya (hybrid culture) dalam masyarakat urban, penulis menggunakan pendekatan teori hibriditas Hommi K. Bhabha dalam kajian ini.

Teori identitas Sheldon Stryker menjelaskan bahwa identitas saling mempengaruhi antara seseorang sebagai individu dengan struktur sosial yang lebih luas (masyarakat). Sementara itu Peter J. Burke, mengatakan bahwa identitas adalah bagaimana orang berperan dalam masyarakat untuk menemukan makna dirinya. Identitas bisa menjadi kontrol dan panduan dalam setiap tindakan manusia. Manusia dalam memperoleh identitas bisa memiliki lebih dari satu identitas menurut perannya yang berbeda dalam interaksi sosial. Dengan demikian, identitas dapat dimaknai diri sebagai ayah, ibu, rekan kerja, teman, dan sebagai salah satu dari sekian banyak kemungkinan peran sesuai yang bisa dimainkan seseorang. ${ }^{16}$

Identitas dalam lingkup sosial memang mempunyai peran yang berbeda sesuai dengan konteks diri, tetapi identitas itu mempunyai kekhasan tertentu yang bisa mengalami perubahan. Identitas dengan sendirinya merupakan satu unsur kunci dari kenyataan subjektif yang berhubungan secara dialektif dengan

\footnotetext{
${ }^{15}$ Sheldon Stryker dan Peter J. Burke, "The Past, Present, and Future of an Identity Theory," Source: Social Psychology Quarterly 63, no. 4 (2000): 284-97, https://pdfs.semanticscholar.org/ d9d9/f9f83697e9de8920190d955b3c427030497b.pdf.

16Jan Assmann dan John Czaplicka, "Collective Memory And Cultural identity," in New German Critique (North Carolina: Duke University Press, 1995), 125-33, https://www.academia.edu/ 10287262/Collective_Memory_and_Cultural_Identity.
} 
masyarakat. Identitas dibentuk oleh proses-proses sosial. Begitu memperoleh wujudnya, ia dipelihara, dimodifikasi, bahkan dibentuk ulang oleh hubunganhubungan sosial. Proses-proses sosial yang terlibat dalam membentuk dan mempertahankan identitas ditentukan oleh struktur sosial. Sebaliknya, identitas individu dan struktur sosial bereaksi terhadap struktur sosial yang sudah diberikan, memeliharanya, memodifikasinya atau membentuknya kembali. ${ }^{17}$ Identitas adalah konsep tentang bagaimana orang mengidentifikasikan dirinya dan diidentifikasi oleh orang lain berdasar ras, etnis, budaya, bahasa dan agama. ${ }^{18}$ Sumber lain menjelaskan bahwa identitas merupakan sumber makna bagi aktor-aktor sendiri dan dikonstruksi oleh mereka sendiri melalui proses individuasi. 19

\section{Identitas dan Perubahan Sosial}

Perkembangan kota memberikan warna baru bagi masyarakat secara luas, baik warna positif maupun negatif. Pembangunan kota-kota besar seperti Semarang dan kota besar lainnya di Indonesia cenderung pada perencanaan dan pengembangan pembangunan kawasan-kawasan perumahan eksklusif, gedung perkantoran, pusat pembelanjaan dan sarana-sarana rekreasi modern. ${ }^{20}$

Menelusuri jejak penyebaran Islam di Kota Semarang, sisa-sisa kejayaan Islam masa itu hingga kini masih tersisa dengan bukti bangunan berupa masjidmasjid kuno. Di beberapa sudut Kota Atlas ini terdapat masjid kuno yang dibangun ratusan tahun silam. Salah satunya Masjid Menara yang terdapat di Jalan Layur, Kampung Melayu Kelurahan Dadapsari, Semarang Utara. Masjid ini bisa dikatakan sebagai masjid tertua. Dalam prasasti yang pernah ditemukan pada masa lampau, masjid itu dibangun pada tahun 1802 Masehi. Salah satu Imam Masjid Menara, Al-Mahsun mengatakan, masjid ini dibangun oleh sejumlah saudagar dari Yaman yang bermukim di ibu kota Jawa Tengah. Para saudagar itu singgah di Semarang seiring dengan perdagangan antar negara melalui perairan. Diceritakannya, pada masa pemerintahan Hindia Belanda sekitar tahun 1743 Masehi, kawasan ini merupakan tempat bermukim penduduk etnis Melayu.

\footnotetext{
17Peter L. Berger dan Thomas Luckman, Tafsir Sosial Atas Kenyataan: Risalah tentang Sosiologi Pengetahuan (Jakarta: LP3ES, 1990), 235-236.

${ }^{18}$ Francis M. Deng, War of Vissions Conflict of Identities in the Sudan (Washington, D.C: The Brooking Institution, 1995), 387.

${ }_{19}$ Manuel Castells, The Power of Identity (Malden MA: Blackwell Publishing, 2003), 7.

${ }^{20}$ Colombijn dan Barwegen, Kota Lama, Kota Baru... 148.
} 
Lambat laun, saudagar-saudagar pedagang dari Melayu itu membentuk sebuah perkampungan sehingga membutuhkan tempat ibadah.

Secara konseptual subjektivitas dan identitas memiliki hubungan erat, bahkan tidak bisa dipisahkan. Seperti yang dikemukakan Chris Barker, ia menegaskan bahwa identitas sepenuhnya merupakan suatu konstruksi sosial budaya. Bahkan identitas tidak serta merta dapat eksis di luar representasi atau akulturasi budaya. ${ }^{21}$

Melalui proses yang digambarkan di atas, masyarakat urban memilliki kesadaran yang tumbuh tentang masalah-masalah bersama, maka kesempatan bekerja terbuka untuk semua anggota kelompok etnis. ${ }^{22}$ Sedangkan dinamika kelompok masyarakat pedesaan, bahwa perpaduan beberapa orang atau kelompok suku atau keturunan di pedesaan dilatarbelakangi oleh dorongan upaya untuk memenuhi kebutuhan yang sama dari sekumpulan individu. Situasi ini oleh Cooley ${ }^{23}$ disebut community atau masyarakat setempat.

Kota-kota terus berubah dan berkembang dalam bentuk baru, di mana identitas urban diciptakan melalui interaksi yang kompleks dari unsur-unsur alam, sosial dan bangunan. Oleh karena itu, lingkungan perkotaan harus dipertimbangkan dari perspektif sejarah, bukan hanya dengan memahami signifikansi historis bangunan, namun melalui evaluasi perkotaan dalam konteks lokal sehubungan dengan aktivitas manusia, bentuk bangunan dan alam. Tingkat yang paling dasar, kota-kota diidentifikasi dalam hal pengaturan geografis mereka, namun unsur-unsur yang dibangun adalah bentuk paling penting dalam mempengaruhi identitas kedua dengan cara yang positif dan negatif dalam waktu singkat. Hal ini juga penting dalam penciptaan "dalam arti tempat", merupakan faktor penting guna mencapai identitas dan keberlanjutan pemukiman per-

\footnotetext{
${ }^{21}$ Chris Barker, Cultural Studies Theory and Practice (New Delhi: Sage Publications, 2004), 170171.

${ }^{22}$ Hans-Dieter Evers, Sosiologi Perkotaan: Urbanisasi dan Sengketa Tanah di Indonesia dan Malaysia (Jakarta: LP3ES, 1982), 58.

${ }^{23}$ Charles Horton Cooley, Human Nature and the Social Order (New York: Scribners, 2005), 5. Cooley populer dengan salah satu konsep dalam karyanya, "Concept of the Looking Glass Self", bahwa konsep hubungan diri ini atau bagaimana seseorang memandang diri sendiri bukanlah fenomena tersendiri melainkan mencakup hal-hal lain. Ia mengatakan bahwa masyarakat dengan individu tidak menunjukkan fenomena yang dapat dipisahkan, namun hanya aspek kolektif dan distributif dari hal yang sama. Lebih lanjut Cooley juga menegaskan bahwa manusia memiliki kecenderungan yang melekat untuk menjangkau, berinteraksi, atau bersosialisasi dengan orangorang atau benda-benda yang mengelilinginya.
} 
kotaan seperti yang dinyatakan oleh banyak teoritis. ${ }^{24}$ Identitas urban erat terkait dengan keberlanjutan perkotaan, faktor penting untuk meningkatkan kualitas kehidupan masyarakat urban, mencakup aspek lingkungan, ekonomi dan sosial.

\section{Konstruksi Kultural Masyarakat Urban}

Masyarakat perkotaan sering diidentikan dengan masyarakat modern dan dipertentangkan dengan masyarakat pedesaan yang akrab dengan sebutan masyarakat tradisional, terutama dilihat dari aspek kulturnya. Masyarakat modern adalah masyarakat yang sebagian besar warganya mempunyai orientasi nilai budaya yang terarah ke kehidupan dalam peradaban masa kini. Pada umumnya masyarakat modern tinggal di daerah perkotaan sehingga disebut masyarakat kota. Masyarakat modern sering dibedakan antara masyarakat pedesaan dengan masyarakat perkotaan. Tetapi perbedaan tersebut tidak mempunyai hubungan dengan pengertian masyarakat sederhana karena dalam masyarakat modern, seberapa pun kecilnya desa, tentu ada pengaruh dari kota. Pembedaan antara masyarakat pedesaan dan masyarakat perkotaan, pada hakikatnya bersifat gradual. Sulit untuk memberikan batasan yang dimaksudkan dengan perkotaan karena adanya hubungan konsentrasi penduduk dengan gejala-gejala sosial yang dinamakan urbanisme.

Masyarakat perkotaan sering disebut urban community. Pengertian masyarakat kota lebih ditekankan pada sifat-sifat kehidupannya serta ciri-ciri kehidupannya yang berbeda dengan masyarakat pedesaan. Perhatian khusus masyarakat kota tidak terbatas pada aspek-aspek seperti pakaian, makanan dan perumahan, tetapi mempunyai perhatian lebih luas lagi. Orang-orang perkotaan sudah memandang penggunaan kebutuhan hidup. Hal ini disebabkan oleh pandangan warga kota sekitarnya. Kalau menghidangkan makanan misalnya, yang diutamakan adalah bahwa yang menghidangkannya mempunyai kedudukan sosial yang tinggi. Kehidupan keagamaan masyarakat perkotaan berkurang jika dibandingkan dengan kehidupan keagamaan di desa. Kegiatankegiatan keagamaan hanya berpusat pada tempat peribadatan, seperti masjid, gereja. Sedangkan di luar itu, kehidupan masyarakat berada dalam lingkungan

${ }^{24}$ Derya Oktay, "How can urban context maintain urban identity and sustainability? Evaluations of Taormina (Sicily) and Kyrenia (North Cyprus)," Web Journal on Cultural Patrimony 2, no. July-Dec (2006): 1-19, http://www.webjournal.unior.it. 
ekonomi, perdagangan. Cara kehidupan demikian mempunyai kecenderungan ke arah keduniawian, jika dibandingkan dengan kehidupan masyarakat desa yang cenderung ke arah keagamaan yang ketat. ${ }^{25}$

Masyarkat perkotaan pada umumnya dapat mengurus dirinya sendiri tanpa harus bergantung pada orang lain. Jalan pikiran rasional yang pada umumnya dianut masyarakat perkotaan, menyebabkan interaksi-interaksi yang terjadi lebih didasarkan pada faktor kepentingan daripada faktor pribadi. Perubahan-perubahan sosial tampak dengan nyata di kota-kota, sebab kota-kota biasanya terbuka dalam menerima pengaruh-pengaruh dari luar. Hal ini sering menimbulkan pertentangan antara golongan satu dengan golongan lainnya. Seperti dikatakan Daniel Lemer dalam teori modernisasinya yang terkenal, bahwa dengan adanya urbanisasi timbul struktur-struktur komunikasi, yang secara psikologi individual dinamakan "empati", yaitu kemampuan psikologis seseorang membayangkan dirinya dalam peranan sosial lain yang ada di waktu itu. $^{26}$

Identitas urban menurut Kevin Lynch, ${ }^{27}$ seorang tokoh peneliti kota, bahwa dalam proses pembentukan sebuah identitas urban terbentuk melalui suatu pengamatan citra atas kota itu sendiri, hal ini dapat berkembang dengan waktu yang lama untuk menjadi sebuah identitas kolektif (masyarakat urban). Risetnya yang cukup populer didasarkan pada citra mental jumlah penduduk dari kota tersebut. Dalam risetnya ia menemukan bahwa betapa pentingnya citra mental karena citra akan memberikan banyak kontribusi penting bagi masyarakatnya, seperti kemampuan untuk berorientasi dengan mudah dan cepat disertai perasaan nyaman, identitas yang kuat terhadap suatu tempat, dan keselarasan hubungan dengan tempat-tempat lain. Menurut Lynch, citra lingkungan merupakan proses dua arah antara pengamat dengan benda yang diamati, atau disebut juga sebagai kesan atau persepsi antara pengamat terhadap lingkungannya. Citra bukanlah identitas urban, melainkan sebuah identitas urban dapat dibentuk oleh proses pemaknaan citra kota.

25Evers, Sosiologi Perkotaan: Urbanisasi dan Sengketa Tanah di Indonesia dan Malaysia, 7-8.

${ }^{26}$ Daniel Lemer, The Passing of Traditional Society (New York: The Free Press, 1958).

${ }^{27}$ Kevin Lynch, The Image of The City (Cambridge, Massachusetts: MIT Press, 1960).

JURNAL THEOLOGIA — Volume 29, Nomor 2, Desember 2018 
Berdasarkan paparan di atas, sifat masyarakat Semarang yang religius, plural, equal dan egaliter direpresentasikan melalui struktur tubuh, kaki, dan ekor Warak Ngendog yag tegak, bersudut dan bergaris lurus, dan hal itu dimaksudkan sebagai simbol konsistensi karakter masyarakat Semarang yang lurus atau apa adanya. Pada akhirnya penulis mengemukakan bahwa karakteristik keberagamaan masyarakat Semarang ditopang oleh empat karakter; religiusitas (berdasar ajaran agama), entrepreneurship (karakter pedagang), equality (sikap terbuka), egality (bebas, kesederajatan sosial). ${ }^{28}$

Kota adalah ruang domisili sekaligus arena sosialisasi dan praktik budaya para pemukimnya. Ekspresi kultural itu dapat diakomodasi secara selayaknya. Dinamika kehidupan masyarakat urban dalam mencari sebuah identitas baru sebagai eksistensi dalam sebuah kelompok atau komunitasnya tak lepas dari kontruksi lingkungan sosial, budaya dan tradisi. Lingkungan, bagi masyarakat urban mendorong untuk mengekspresikan diri dan terlibat dalam komunitas atau pengorganisasian sebuah pemukiman. Pada situasi inilah masyarakat urban akan menentukan identitasnya yang baru. ${ }^{29}$

Studi-studi sosial secara definitif mengenal istilah pembedaan masyarakat dalam dua tipologi, yaitu masyarakat pedesaan dan perkotaan. Desa didefinisikan sebagai wilayah sosial dengan karakteristik khas masyarakatnya, seperti mengutamakan harmonisasi ketimbang konflik, mematuhi nilai tradisional, memiliki semangat kolektivitas, kekeluargaan, dan berbagai karakteristik sopansantun atau ramah-tamah lainnya. Sedangkan kota digambarkan sebagai wilayah yang dihuni oleh masyarakat berkarakteristik individualis, egois, kompetitif, produktif, dan berbagai karakteristik manusia modern lainnya. Menilik pada tipologi tersebut, Durkheim menyatakan bahwa perubahan yang terjadi adalah masyarakat solidaritas mekanik ke masyarakat solidaritas organik.30

Identitas bukanlah sesuatu yang melekat begitu saja, tetapi merupakan serangkaian proses yang terus berkembang menjadi seperti yang tercitrakan. Mereka membuat dan mendefinisikan dirinya dalam sebuah kontruksi yang

28Djawahir Muhammad, Semarangan Lintas Sejarah dan Budaya (Semarang: Pustaka Semawis, 2016), 104.

${ }^{29}$ Lebih lanjut baca: Derya Oktay, "The Quest for Urban Identity in the Changing Context of the City Northern Cyprus," Cities: The International Journal of Urban Policy and Planning 19, no. 4 (2002): 261-71, https://doi.org/10.1016/S0264-2751(02)00023-9.

${ }^{30}$ Emile Durkheim, The Division of Labour in Society (New York: The Free Press a Dvision of Macmillan, 1984). 
ideal tentang diri mereka. Sebagai konsekuensinya mereka akan tergabung dalam sebuah solidaritas kebersamaan atas dasar gagasan yang serupa. Dengan demikian, proses identifikasi seseorang dari pengaruh lngkungan sosial sehingga melahirkan sebuah identitas baru sangat dimungkinkan. Canclini 31 mengintrodusir kecenderungan persentuhan budaya antar kultur ini sebagai budaya hibrida atau hybrid culture.

Upaya mewujudkan identitas urban seperti yang diintrodusir oleh Homi K Bhabha dalam karyanya "The Location of Culture", bahwa keterikatan multikultural merupakan hasil dari kesadaran bersama atas apa yang dirasakan bersama oleh masyarakat tradisional yang lahir sepanjang sejarah itu terjadi. Bahkan suatu perbedaan dalam lintas budaya bukanlah sesuatu penghalang atas kesadaran di mana mereka menempati ruang yang sama. Pemahaman atas hibriditas ini bukan sekedar nalar final atau sebuah realitas, tetapi bagaimana kita menuju artikulasi aktivitas manusia yang memberi nilai rasionalitas yang ia rasakan. ${ }^{32}$

Dalam konteks Semarang, representasi paling kental dari beragam bentuk ekspresi budaya hybrid di kota Semarang adalah persentuhan budaya Jawa dengan budaya Islam. Manivestasinya terdapat pada beberapa ritul; mulai dari upacara turun tanah (tedhak siti) bagi anak-anak, khitanan atau supit (khitan) bagi remaja, perhelatan nikah/upacara perkawinan, sampai upacara pemakaman. Dalam upacara-upacara itu orang Semarang dengan nyaman menjalankan bersama-sama tradisi Jawa dan tradisi Islam. Mereka tidak mempersoalkan apakah hal itu diklarifikasi sebagai khufarat atau sinkretik, yang penting dapat melakukannya dengan nyaman. Pada sisi yang lain orang Semarang memiliki warisan budaya sebagai seorang pedagang. Seorang pedagang memiliki kebebasan lebih banyak dari seorang pegawai. Mereka boleh mengatur jadwal

\footnotetext{
${ }^{31}$ Studi tentang hibriditas telah mengubah pembicaraan tentang identitas, budaya, perbedaan, ketidaksetaraan, multi budaya, dan tentang pasangan konseptual yang digunakan untuk mengatur konflik dalam ilmu sosial. Yakni tradisi atau modernitas, lokalitas atau global. Mengapa isu hibriditas begitu penting, bagi Canclini istilah hibriditas secara khusus untuk mengidentifikasi dan merupakan hasil dari karakterisasi konsekuensi sejak awal modernitas, bahasa elit dan populer pasca terjadinya ekspansi Eropa ke Amerika. Canclini berpendapat bahwa inti dari gagasan budaya hibrid adalah gagasan antropologi yang berfokus pada tradisi dan sosiologi dengan berkonsentrasi pada modernitas. Di samping itu juga studi hibriditas ini merupakan disiplin dalam mempelajari produksi ketidaksetaraan melalui segmentasi pasar tenaga kerja di mana perbedaan dalam pekerjaan, gaji, dan status beralih ke kelompok yang berada berdasarkan faktor-faktor kelas, jenis kelamin, dan ras. Canclini, Hybrid Cultures: Strategies for Entering and Leaving Modernity (Minneapolis London: University of Minnesota Press, 1995).
}

${ }^{32}$ Bhabha, The Location of Culture, 245-247. 
kegiatannya sendiri, boleh menentukan sendiri berapa target penghasilannya. Perilaku mereka ini barangkali berasal dari lingkungan pesisir yang dipengaruhi ajaran agama Islam; tidak membeda-bedakan derajat atau egaliter. Mereka juga memiliki karakter equal, dapat menerima budaya dari manapun datangnya. 33

Kota Semarang merupakan kota metropolitan yang di dalamnya memiliki beragam etnik. Hal ini dapat mempengaruhi bagaimana karakteristik keberagamaan masyarakat urban di Semarang yang pluralis. Kecenderungan pluralisme itu bahkan telah berkembang sejak kota ini didirikan oleh Ki Ageng Pandanaran 469 tahun silam. Pluralisme budaya dan heteroginitas masyarakat Semarang telah mendorong tumbuhnya persemaian dua budaya atau lebih dari etnis yang berbeda, yang melahirkan sebuah entitas budaya "baru". 34

\section{E. Simbol Warak Ngendog sebagai Identitas Muslim Urban di Kota Semarang}

Dinamika keagamaan Muslim Urban Kota Semarang mengalami perubahan secara signifikan. Pengaruh teknologi yang terjejaring di dunia menjadi ladang ekspresi keagamaan yang sangat terbuka. Dukungan televisi dan media sosial memudahkan perkembangan ekspresi keagamaan, seperti dakwahdakwah serta majlis dzikir sebagai salah satu aktivitas spiritualitas masyarakat Muslim urban. Ungkapan-ungkapan sufisme baru di Indonesia, misalnya yang mengandung tren global dalam pemikiran keagamaan dan kultur sekuler telah menjadi menarik bagi Muslim urban sejak akhir abad yang lalu. Di mana bentukbentuk sufisme ini telah dipromosikan melalui jalur-jalur komunikasi baru, terutama institusi-institusi pendidikan Islam bergaya universitas dan siaransiaran di televisi Islami. ${ }^{35}$

Kesadaran komunal masyarakat Muslim urban diiringi dengan tumbuhnya komunitas-komunitas pengajian di masjid-masjid. Bangkitnya modernitas yang diiringi dengan munculnya budaya global pada akhirnya menimbulkan alienasi hingga melahirkan krisis kepercayaan dan identitas pribadi. Dengan perkembangan dunia yang serba modern, kepercayaan terhadap prinsip impersonal

\footnotetext{
${ }^{33}$ Muhammad, Semarangan Lintas Sejarah dan Budaya, 122-123.

${ }^{34}$ Amen Budiman, Semarang Riwayatmu Dulu (Semarang: Tanjung Sari, 1978), 96.

${ }^{35}$ Greg Fealy dan Sally White, Ustadz Seleb, Bisnis Moral dan Fatwa Online: Ekspresi Islam Kontemporer (Jakarta: Komunitas Bambu, 2012), 54.
} 
maupun terhadap orang lain yang tidak dikenal menjadi sesuatu yang tidak dapat dipisahkan dari eksistensi sosial. 36

Gejala modernisme di atas berdampak pada kedangkalan dalam beragama, bersosial dan identitas Indonesia. Mempertahankan tradisi lokalitas yang dirumuskan di publik merupakan identitas baru masyarakat urban sebagai eksistensi sosialnya, sehingga kesadaran komunal sebagai identitas masyarakat urban dapat dielaborasi dengan lahirnya hibriditas kebudayan serta kolektifitas masyarakat urban dalam multikulturalisme ini. Karenanya, Kota Semarang sebagai kota multikultural dapat dirumuskan melalui relasi kebudayaan antar etnis yang telah berkembang menjadi sebuah identitas baru.

Ciri masyarakat Muslim urban kota Semarang terlihat di beberapa bagian wilayah kota ini dengan tradisi keagamaannya yang sangat tradisional, misalnya di kawasan Kauman kota lama, Gunungpati, dan Tembalang. Mereka masih melakukan kegiatan amalan keagamaan tradisional, ${ }^{37}$ dan dari cara beribadahnya teridentifikasi warga Nahdlatul Ulama. ${ }^{38}$

Secara geografis, masyarakat Muslim tradisional di Kota Semarang, lebih dominan di wilayah pinggir yang berbatasan dengan Kabupaten Demak, Kabupaten Kendal dan Kabupaten Semarang. Kebudayaan masyarakat Muslim yang berada di pinggir itu merefleksikan sebuah pola keberagamaan yang berbeda dengan mereka yang berada di tengah. Warga Kota Semarang yang berada di pinggir lebih banyak memerankan pola-pola solidaritas mekanis. Ciri seperti ini, sangat melekat pada kategori masyarakat tradisional.

Pada masyarakat Mulim urban di Kota Semarang, situasi zaman di era pasca reformasi menjadikannya lebih terbuka. Salah satu karakteristik masya-

36Rofhani Rofhani, "Budaya Urban Muslim Kelas Menengah," Teosofi: Jurnal Tasawuf dan Pemikiran Islam 3, no. 1 (2015): 181-210, https://doi.org/10.15642/teosofi.2013.3.1.181-210.

${ }^{37}$ Semarang memiliki upacara rutin sebagai tradisi masyarakat Semarang, yakni Tradisi Dugderan, salah satu tradisi yang selalu ditunggu-tunggu oleh warga Kota Semarang dalam setiap tahunnya. Tradisi ini berawal dari adanya suara dug-dug-dug bedug Masjid Agung Kauman yang kini diistilahkan Masjid Agung Semarang, dan der-der-der suara petasan yang dinyalakan di Kanjengan. Suara tersebut merupakan tanda bahwa esok hari adalah pertama bulan Ramadhan. Dalam perkembangannya, terciptalah tradisi Dugderan dan diakhiri dengan karnaval. Pada awalnya karnaval tersebut diikuti oleh masyarakat Kauman. Seiring perkembangannya kini selain masyarakat Kauman, karnaval ini telah pula diikuti oleh warga Semarang khususnya yang beragama Islam. Lihat: Wijanarka, Semarang Tempo Dulu: Teori Desain Kawasan Bersejarah (Yogyakarta: Ombak, 2007), 16.

38Interview dengan Djawahir Muhammad, budayawan Semarang, pada tanggal 27 Maret 2017 dilakukan di kediamannya, di Semarang.

JURNAL THEOLOGIA - Volume 29, Nomor 2, Desember 2018 
rakat urban kota Semarang adalah berasal dari berbagai etnis. Seiring dengan pergumulan budaya dengan beragam bangsa dan sub-sub etnis di Nusantara yang terjadi selama berabad-abad, terbentuklah budaya lokal Semarangan. ${ }^{39}$ Mereka tetap mempertahankan nilai-nilai lokalnya ${ }^{40}$ di satu sisi, tetapi juga menerima unsur-unsur luar. Hal itu misalnya terlihat pada ekspresi budaya dalam tradisi Dugderan yang bernuansa religious Islam, dan budaya hybrid yang memadukan beragam elemen budaya, etnis dan agama. 41

Pada tahun 1881an, Warak Ngendog sebagai simbol dalam tradisi Dugderan, terbuat dari bahan yang sangat sederhana seperti kayu, bambu dan sabut kelapa. Namun sekarang ini, bahan-bahan yang digunakan lebih kompleks, meliputi kayu, kertas minyak ditambah berbagai ornamen dari kertas karton, gabus dan sebagainya. Amin Budiman dan Djawahir Muhammad, tidak bisa menyebutkan siapa pembuat Warak Ngendog karena tidak pernah ada dalam catatan sejarah. ${ }^{42}$ Menurut Supramono, bahwa ide Warak Ngendog berkaitan dengan tradisi Dugderan dalam menyambut bulan Ramadlan untuk memeriahkan acara seusai ritual musyawarah dan pembacaan pengumuman awal puasa bahwa perlu dipukul bedug dan disulutnya meriam sebagai simbol pemersatu antara ulama dengan pemerintahan. Dalam perkembangannya ditemukan tiga kelompok Warak Ngendog berdasarkan bentuknya, yaitu: 1) Menilik bentuk Warak Ngendog klasik, yakni Warak Ngendog yang masih menampilkan unsur dan struktur asli serta diciptakan turun-temurun dalam wujud yang sama. Di mana kepalanya terdiri dari bagian mulut bergigi tajam, mata melotot, telinga tegak atau tanduk, jenggot yang panjang lebat. Begitu pun dengan badan, leher dan keempat kakinya ditutup bulu yang terbalik dengan warna berselang-seling merah, kuning, putih, hijau dan biru. Warak Ngendog klasik juga terdapat ekor panjang, kaku melengkung berbulu serupa badan dan terdapat surai di ujungnya. Bentuk telur atau endhog terletak di antara dua kaki belakangnya. 2) Warak Ngendog yang bentuknya sudah dimodifikasi, secara

\footnotetext{
${ }^{39}$ Budaya lokal yang dimaksudkan di sini adalah perilaku sehari-hari masyarakat Semarang yang berbasis pada nilai-nilai tradisi yakni ekspresi budaya yang berorientasi pada spirit Jawa pesisiran.

40Penghayatan spiritualitas orang Jawa kental dengan ritus-ritus lokalitas. Kesadaran manusia dalam pencapaiannya akan kehadiran realitas ketuhanan dapat ditempuh melalui pengalaman titah dari pusat hati, lewat suara tanpa rupa sebagai upaya menemukan kesucian sejati. Lihat: Setyo Hajar Dewantoro, Suwung Ajaran Rahasia Leluhur Jawa (Banten: Javanica, 2017), 10.

${ }^{41}$ Muhammad, Semarangan Lintas Sejarah dan Budaya, 104.

42Supramono, "Makna Warak Ngendog dalam Tradisi Ritual Dugderan di Kota Semarang" (Universitas Negeri Semarang, 2007), 93-95.
} 
umum sama dengan Warak Ngendog klasik. Perbedaannya hanya di bagian kepala yang mirip dengan kepala naga. Ada kesamaan bentuk naga Cina atau naga Jawa. Mocong yang mirip buaya dengan deretan gigi tajam, lidah bercabang menjulur, mata melotot, berkumis dan berjanggut, bertanduk kecil bercabang seperti rusa, kulit bersisik, bersurai di bagian belakang kepala. Naga Jawa biasanya memakai mahkota di atas kepalanya. 3) Warak Ngendog kontemporer, secara struktur bentuknya sama dengan Warak Ngendog klasik, namun detaildetail kepala dan bulu tidak sesuai. Misalnya kepalanya seperti harimau, bulunya tidak terbalik, tidak berbulu tapi bersisik dan sebagainya. ${ }^{43}$

Ada ragam pendapat mengenai binatang Warak ini. Ada yang berpendapat bahwa binatang Warak ini merupakan perwujudan dari binatang sakti dalam kebudayaan Islam. Ada pula yang mengatakan, karena kota Semarang merupakan kota pelabuhan, maka tidak mustahil terjadi pembauran kebudayaan berbagai bangsa pendatang, di mana Warak ini menyerupai binatang dalam mitos kebudayaan Cina. ${ }^{44}$

Perbedaan pandangan tentang binatang yang disebut Warak ini diakui oleh Supramono dalam penelitiannya. Supramono mengatakan bahwa ada anggapan bahwa Warak ini berasal dari perpaduan beberapa simbol budaya. Binatang itu berkepala Kilin sebagai lambang binatang paling berkuasan dan berpengaruh di Cina dan badan Buroq sebagai binatang Nabi Muhammad saat Isra' Mi'raj. Ada juga yang berpendapat bahwa Warak berkepala naga, binatang simbol milik orang Cina dan badan kambing, binatang yang banyak dimiliki orang pribumi Jawa dan sering digunakan untuk berkorban saat Idul Adha.

Ada pendapat yang mengatakan bahwa Warak merupakan hadiah dari warga Cina agar digunakan untuk memeriahkan tradisi ritual Dugderan sebagai bukti ketulusan mereka untuk bersatu dan berdamai guna menebus kesalahannya waktu membakar masjid besar saat pemberontakan warga Pecinan dulu. Namun pendapat tersebut sangat lemah dasarnya, karena hanya mengacu pada pembentukan kepala Kilin atau naga pada Warak Ngendog. Sementara dari unsur nama, bentuk keseluruhan dan makna karya lebih dominan pengaruh kebudayaan Jawa dan Islam. ${ }^{45}$ Disebutkan dalam buku Semarang Tempo Doeloe,

\footnotetext{
${ }^{43}$ Supramono.

${ }^{44}$ Jongkie Tio, Kota Semarang dalam Kenangan (Semarang: Lembaga Kotamadya Daerah Tingkat II Semarang, 2007), 37.

${ }^{45}$ Supramono, “Makna Warak Ngendog dalam Tradisi Ritual Dugderan...” 88-9.
}

JURNAL THEOLOGIA — Volume 29, Nomor 2, Desember 2018 
bahwa Legirah, seorang pembuat Warak Ngendog dari Kampung Purwodinatan Semarang, tidak mengetahui warak itu binatang apa, dia hanya bisa membuat. Dia menuturkan bahwa dia juga berpikir terus kenapa binatang kakinya empat dan punya daun telinga tapi bisa memiliki telur. ${ }^{46}$

Belum lama ini, ada warga Trimulyo Genuk, $\mathrm{H}$ Kholid yang mengaku mempunyai sanad kesaksian atas sejarah awal mula Warak Ngendog dan tradisi Dugderan. Dia mengaku bahwa Warak Ngendog diciptakan oleh Kyai Abdul Hadi seorang seniman, mantan tukang kayu dan pandai mendalang dan membuat patung hewan yang sampai sekarang dikenal dengan Warak Ngendog. Menurutnya, Kyai Abdul Hadi merangkai kayu dan rumput menjadi hewan sebagai simbol nafsu manusia, yaitu bersisik, mulutnya menganga dengan gigi bertaring, serta bermuka seram dengan badan seperti kambing. Itu gambaran nafsu yang harus dikalahkan dengan puasa. Maskot yang dilengkapi dengan telur (endhog) ini maksudnya apabila seseorang bisa bersikap wira'i atau warak yang artinya menjaga nafsunya, maka akan mendapatkan ganjaran yang disimbolkan dengan telur atau endhog. Demikianlah, keragaman budaya multietnik terlihat dalam keutuhan karya yang disebut dengan Warak Ngendog.

Kesaksian H. Kholid tersebut seperti tertuang dalam beberapa pernyataan berikut:

"Guru saya, Kiai Masrur mendapat cerita dari gurunya, Kiai Zaid. Kiai Zaid yang merupakan kakek dari Mbah Munif Girikusumo ini mendapat riwayat dari gurunya, Kiai Abdul Hadi. Mbah Hadi inilah sahabat sekaligus guru ngaji Adipati Surohadimenggolo alias Simbah Terboyo. Kita tahu, beliau adalah waliyullah yang makamnya ada di belakang masjid keramat Terboyo." 47

Inti dari kisah bersambung tersebut, jelas Kholid, Adipati Surohadimenggolo yang memerintah di masa VOC berkeluh kesah kepada gurunya, Mbah Hadi. Sang Adipati ingin berbuat sesuatu untuk membimbing ibadah rakyatnya dalam berpuasa. Mbah Hadi menyarankan agar Bupati membuat pertemuan dengan rakyat dan membuat tengara masuknya bulan puasa. Usul Kiai Abdul Hadi diterima Adipati Surohadimenggolo. Dia pun meminta tolong guru sekaligus sahabatnya itu untuk membuat maskot acara pertemuan besar yang digagasnya itu. Kiai Abdul Hadi yang seorang seniman, mantan tukang kayu dan 2006), 114.

${ }^{46}$ Edy Muspriyanto, Semarang Tempo Doeloe: Meretas Masa (Semarang: Terang Publishing,

${ }^{47}$ Hamzah Sahal, "Ihwal Warak Ngendok dan Dugderan," NU Online, 2011, http://www.nu. or.id/post/read/33261/ihwal-warak-ngendok-dan-dugderan. Diakses 30 Maret 2018 
pandai mendalang, membuat patung hewan yang sampai sekarang kita kenal sebagai WarakNgendog.

"Mbah Hadi merangkai kayu dan rumput menjadi hewan simbol nafsu manusia. Yaitu bersisik, mulutnya menganga dengan gigi bertaring, serta bermuka seram dengan badan seperti kambing. Itu gambaran nafsu yang harus dikalahkan dengan puasa. Maskot ciptaan Kiai Hadi itu dilengkapi telur. Sang guru ini menerangkan kepada adipati muridnya, bahwa jika orang bisa bersikap wira'i atau warak yang artinya menjaga nafsunya, maka akan dapat ganjaran. Simbolnya telur alias endog. Puas dengan maskot tersebut, Adipati Hadimenggolo lantas mengumumkan kepada warga Semarang untuk berkumpul di alun-alun (depan Masjid Kauman sekarang). Dia lalu meminta takmir masjid Kauman membunyikan meriam tanda akan datangnya bulan Ramadhan. Sejak saat itu, masyarakat membuat Warak Ngendog sebagai simbol datangnya Ramadhan".48

Bunyi meriam dug dan der itulah yang kemudian melahirkan istilah Dugderan, yaitu nama festival menyambut bulan puasa. Sedangkan masyarakat desa, termasuk Demak, mengenal istilah Megengan untuk menyebut masa itu. Megengan dalam bahasa Jawa berarti mengekang atau manahan. Maksudnya mengekang hawa nafsu yang istilah Arabnya Warak itu (wara). Lantas, pertanyaan pun muncul mengapa selama ini Pemkot Semarang menyebut festival Dugderan dicanangkan oleh Adipati Aria Purbaningrat pada tahun 1881. Berkaitan dengan hal ini Kholid sebagai sejarawan Semarang, mengaku tidak tahu dasar Pemkot mengambil tokoh tersebut. Yang jelas, Kholid mendapat cerita seperti yang selama ini beredar di masyarakat.

Sampai sekarang, orang desa menyebut festival jelang Ramadhan adalah megengan. Kalau orang kota lebih sering mendengar istilah Dugderan. Sebab memang penanda datangnya puasa adalah bunyi meriam di masjid Kauman, Dug dan Der. Saya mendapat cerita secara mutawatir (berkesinambungan) dari jalur keilmuan guru saya hingga gurunya Adipati. Saya kira sejarah Semarang memang perlu diteliti kembali dan dicari titik temunya". 49

Melalui tradisi Dugderan ini Muslim urban kota Semarang mampu merumuskan simbol-simbol ritual warisan leluhur sebagai tameng tradisi yang kuat sebagai masyarakat urban. Terlihat di sini, masyarakat urban membangun

${ }^{48}$ Sahal.

${ }^{49}$ Sahal.

JURNAL THEOLOGIA - Volume 29, Nomor 2, Desember 2018 
tradisi kolektif tidak melulu dihubungkan dengan pembagian kerja, namun masih banyak masyarakat urban yang memiliki perayaan kebudayaan mengikat sebagai solidaritas sosial.

Salah satu fungsi ritual adalah menghadirkan kembali nilai-nilai yang sering dilupakan karena kesibukan keseharian. Fungsi ritual ini, selain menguatkan kembali masyarakat Muslim urban juga sebagai pengingat hal-hal penting lain ketimbang kesibukan bekerja. Ritual merupakan indeks bagi sebuah struktur yang terbangun dari kelompok-kelompok itu. Ritual lebih penting dari struktur karena merupakan ekspresi langsung dari struktur pengelompokan itu sendiri. Ritual tidak hanya mengekspresikan tetapi juga menguatkan kembali penghormatan yang dimiliki seseorang terhadap objek-objek sakral. Di sini masyarakat Muslim urban telah mewujudkannya dalam bentuk ritual Dugderan.

Menilik proses ritual yang berkembang sepanjang sejarah secara intens setiap tahunnya, penulis melihat setidaknya Warak Ngendog dalam tradisi Dugderan merupakan bagian dari representasi identitas Muslim urban di Kota Semarang. Terlihat, pola relasi keberagamaan dan ritual simbol-simbol kebudayaan menjadi khas bagi kalangan masyarakat Muslim urban di Kota Semarang. Masyarakat yang notabenenya sangat individualis dan rasional, namun masih menjaga tradisi lokalitasnya. Barangkali ini terjadi tidak hanya di Kota Semarang, tetapi paling tidak Semarang merupakan salah satu dari kotakota lain di Indonesia yang masih kental denga nuansa santri dan hibriditasnya.

\section{F. Kesimpulan}

Tradisi Dugderan yang diwarnai dengan simbol Warak Ngendog dapat dijadikan sebagai relasi multiagama dalam perspektif agama-gama. Simbol Warak Ngendog dapat merepresentasikan keterbukaan bagi sesama manusia, di mana Semarang menjadi salah satu contoh kota yang memiliki masyarakat multikultural.

Tradisi Dugderan seperti dipaparkan pada makna Warak Ngendog merupakan simbol identitas masyarakat Kota Semarang sebagai representasi agama sipil yang di dalamnya mengandung nilai-nilai kesetaraan, solidaritas, dan keterbukaan. Religiositas masyarakat Muslim urban di Kota Semarang ditopang oleh kekuatan kultur dan tradisi yang masih dijaga dalam lingkungan masyarakatnya. 
Tradisi Dugderan dengan beragam simbol etnisitas di dalamnya merupakan salah satu tradisi yang berkembang sejak tahun 1881 M di Masjid Besar Kauman Semarang, dan ia menjadi jembatan bertahannya Islam tradisional di Kota Semarang. Sebagaimana perkembangan permukiman dengan nuansa santri di beberapa wilayah pinggiran kota misalnya, kota Semarang bisa dikatakan menjadi salah satu kota santri di Indonesia. Terbentuknya identitas dan karakteristik masyarakat Muslim urban kota Semarang merupakan salah satu ekspresi keberagamaan dalam multikulturalisme di Indonesia.[]

\section{DAFTAR PUSTAKA}

Assmann, Jan, dan John Czaplicka. "Collective Memory and Cultural identity." In New German Critique, 125-33. North Carolina: Duke University Press, 1995. https://www.academia.edu/10287262/Collective_Memory_and_ Cultural_Identity.

Barker, Chris. Cultural Studies Theory and Practice. New Delhi: Sage Publications, 2004.

Baskara, Benny. Islam Bajo Agama Orang Laut. Banten: Javanica, 2016.

Berger, Peter L., dan Thomas Luckman. Tafsir Sosial atas Kenyataan: Risalah tentang Sosiologi Pengetahuan. Jakarta: LP3ES, 1990.

Bhabha, Homy K. The Location of Culture. New York: Routletge, 1994.

Budiman, Amen. Semarang Juwita: Semarang Tempo Doeloe, Semarang Masa Kini dalam Rekaman Kamera. Semarang: Tanjung Sari, 1979.

——C. Semarang Riwayatmu Dulu. Semarang: Tanjung Sari, 1978.

Canclini. Hybrid Cultures: Strategies for Entering and Leaving Modernity. Minneapolis London: University of Minnesota Press, 1995.

Castells, Manuel. The Power of Identity. Malden MA: Blackwell Publishing, 2003.

Colombijn, Freek, dan Martine Barwegen. Kota Lama, Kota Baru: Sejarah KotaKota di Indonesia Sebelum dan Setelah Kemerdekaan. Terj. Purnawan Basundoro dan Johny Alfian Kusyairi. Yogyakarta: Ombak, 2005.

Cooley, Charles Horton. Human Nature and the Social Order. New York: Scribners, 2005.

JURNAL THEOLOGIA — Volume 29, Nomor 2, Desember 2018 
Deng, Francis M. War of Vissions Conflict of Identities in the Sudan. Washington, D.C: The Brooking Institution, 1995.

Dewantoro, Setyo Hajar. Suwung Ajaran Rahasia Leluhur Jawa. Banten: Javanica, 2017.

Durkheim, Emile. The Division of Labour in Society. New York: The Free Press a Dvision of Macmillan, 1984.

Evers, Hans-Dieter. Sosiologi Perkotaan: Urbanisasi dan Sengketa Tanah di Indonesia dan Malaysia. Jakarta: LP3ES, 1982.

Fealy, Greg, dan Sally White. Ustadz Seleb, Bisnis Moral dan Fatwa Online: Ekspresi Islam Kontemporer. Jakarta: Komunitas Bambu, 2012.

Geertz, Clifford. The Social History of an Indonesia Town. Ithaca, N.Y: M.IT. Press, 1967.

Joe, Liem Thian. Riwajat Semarang: Dari Djamannja Sam Poo Sampe Terhapoesnja Kongkoan. Semarang: Ho Kiem Yoe, 1933.

Lemer, Daniel. The Passing of Traditional Society. New York: The Free Press, 1958.

Lynch, Kevin. The Image of The City. Cambridge, Massachusetts: MIT Press, 1960.

Mead, George H., dan Charles W. Morris. "Mind, Self, and Society from the Standpoint of a Social Behaviorist." The Philosophical Review 44, no. 6 (1935): 587-89. https://doi.org/10.2307/2179928.

Muhammad, Djawahir. Semarangan Lintas Sejarah dan Budaya. Semarang: Pustaka Semawis, 2016.

Muspriyanto, Edy. Semarang Tempo Doeloe: Meretas Masa. Semarang: Terang Publishing, 2006.

Oktay, Derya. "How can urban context maintain urban identity and sustainability? Evaluations of Taormina (Sicily) and Kyrenia (North Cyprus)." Web Journal on Cultural Patrimony 2, no. July-Dec (2006): 1-19. http://www.webjournal.unior.it.

- _- "The Quest for Urban Identity in the Changing Context of the City Northern Cyprus." Cities: The International Journal of Urban Policy and Planning 19, no. 4 (2002): 261-71. https://doi.org/10.1016/S02642751(02)00023-9. 
Rofhani, Rofhani. "Budaya Urban Muslim Kelas Menengah." Teosofi: Jurnal Tasawuf dan Pemikiran Islam 3, no. 1 (2015): 181-210. https://doi.org/ 10.15642/teosofi.2013.3.1.181-210.

Sahal, Hamzah. "Ihwal Warak Ngendok dan Dugderan." NU Online, 2011. http://www.nu.or.id/post/read/33261/ihwal-warak-ngendok-dandugderan.

Stryker, Sheldon, dan Peter J. Burke. "The Past, Present, and Future of an Identity Theory." Source: Social Psychology Quarterly 63, no. 4 (2000): 284-97. https://pdfs.semanticscholar.org/d9d9/f9f83697e9de8920190d955b3c 427030497b.pdf.

Sudarwani, M. M. "Simbolisasi Rumah Tinggal Etnis Cina: Studi Kasus Kawasan Pecinan Semarang." Jurnal Imiah Momentum 8, no. 2 (2012): 19-27. https://publikasiilmiah.unwahas.ac.id/index.php/MOMENTUM/article/v iew/429.

Supramono. "Makna Warak Ngendog dalam Tradisi Ritual Dugderan di Kota Semarang." Universitas Negeri Semarang, 2007.

Svarajati, Tubagus P. Pecinan Semarang dan Dar-Der-Dor Kota. Semarang: Bukusaya, 2016.

Syam, Nur. Islam Pesisir. Yogyakarta: LKiS, 2005.

Tio, Jongkie. Kota Semarang dalam Kenangan. Semarang: Lembaga Kotamadya Daerah Tingkat II Semarang, 2007.

Wijanarka. Semarang Tempo Dulu: Teori Desain Kawasan Bersejarah. Yogyakarta: Ombak, 2007.

Zacot, Francois Robert. Orang Bajo Suku Pengembara Laut: Pengalaman Seorang Antropolog. Jakarta: KPG, 2002. 
